\title{
An over view on green house gas emission characteristics and energy evaluation of ocean energy systems from life cycle assessment and energy accounting studies
}

\section{Subhashish Banerjee*, L. Duckers and R. E Blanchard ${ }^{1}$}

Department of Business, Environment and Society, Coventry University, Priory Street, CV1 5FB, UK

${ }^{1}$ Department of Electronics and Electrical Engineering, Loughborough University, Leicestershire, LE11, 3TU, UK

*Corresponding author. E-mail: wave.banerjee@ gmail.com

Received: M ay 28, 2013; Revised received: August 18, 2013; Accepted: October 15, 2013

Abstract: An analysis has been made as regards emission characteristics of ocean energy systems from life cycle assessment and scope of energy availability from energy accounting studies. Assessment tools developed and standardized were the indices like scope of Green house gases (GHG) emission per kWh power generation, percentage of $\mathrm{CO} 2$ saved compared to coal fired power station and the energy payback period. Emission characteristics of ocean energy systems were also compared with that from solar power, bio-fuels and wind energy systems. Four case studies were made comprising of wave energy converters, Ocean Thermal Energy Conversion (OTEC) system and tidal energy. It could be observed that $\mathrm{CO} 2$ emission percentage saved from ocean energy schemes were more than 95 per cent; and energy payback period varied between one year and a little higher than two years, depending on the type of the device.

Keywords: Barrage, Energy accounting, Global warming, Ocean thermal energy, Pelamis, Wave dragon

INTR ODUCTION
Like all other renewable energy schemes, application of
life cycle analysis (LCA) are useful for the ocean
energy (OE) schemes as well, to assess the degree of
benefits accrued from the saving of GHG emission.
Energy payback period (EPBP) estimations from energy
accounting (EA) studies are also considered important
criterion for evaluating the scope of acceptability of the
concerned OE device for power generation. The OE
types considered in the present study include all three
OE systems comprising of the wave schemes, ocean
thermal energy conversion (OTEC) systems, as well as
of the tidal energy (Thresher and Musial, 2010)
It may be relevant to add that though large scale
commercial application of OE systems, other than barrage,
are yet to come up; but pilot plant studies have proved
successful in number of OE devices for all three OE
systems. Case studies of some of the OE devices that
have the potential of commercial application have been
taken up in the present study. The scope of GHG emission
saving capability as also of energy payback periods have
been estimated from LCA and EA studies, respectively
(Helius and Reinout, 2007). In the present study, the case
studies taken up included- two wave energy converters
(Pelamis and Wave Dragon), one type of OTEC scheme
(CC-OTEC) and a proposed barrage project (Severn
barrage). A brief account of LCA and EA studies of above
4 cases are appended below.

Methodology adopted in LCA and EA estimations: Life time emission of GHGs expressed in $\mathrm{g} / \mathrm{kWh}$ power generation of an energy device, as per LCA estimations, would be $=\sum \mathrm{Gi} \times \mathrm{Mi} / \mathrm{P}_{\mathrm{i}}+$ operational stage emission in $\mathrm{g} / \mathrm{kWh}$.

In the above equation, Gi represents the gas emission in $\mathrm{kg} / \mathrm{kg}$ of the inventory items; Mi is mass of the inventory items of the device; and $\mathrm{P}_{1}$ is the life time power generation of the device, expressed in $\mathrm{kWh}$. Like all other renewable energy systems, in case of OE systems also the operational stage emission would be rather marginal, excepting OTEC schemes which do contribute some emission in its operational stage as well.

Likewise, energy payback period $(\mathrm{EPBP})$ would be $=\sum \mathrm{Ei}$ $\mathrm{Mi} / \mathrm{Pa}$;

Where, Ei is the embodied energy of the inventory items of the device expressed in $\mathrm{MJ} / \mathrm{kg}$; $\mathrm{Mi}$ is their respective mass in $\mathrm{kg}, \mathrm{Pa}$ is the annual power generated by respective OE devices, also expressed in MJ (Mega Joule).

The data as regards $\mathrm{Gi}$ of inventory items was adopted from Danish model of LCA estimations as used for wind energy systems (Schleisner, 2000), estimating the emission characteristics of construction materials of $\mathrm{OE}$ devices as per ISO 14040 with LCA boundary conditions of 'cradle to gate' (ISO 14040, 2006). The results obtained as regards $\mathrm{CO}_{2}$ emission in particular, were corroborated 
Table 1. Emissions in $\mathrm{kg} / \mathrm{kg}$ of the construction materials as per the Danish model of LCA (Schleisner, 2000).

\begin{tabular}{lccccc}
\hline$M$ aterials concer ned & $\mathrm{CO}_{2}(\mathrm{~kg})$ & $\mathrm{NO}_{x}(\mathrm{~kg})$ & $\mathrm{N}_{2} \mathrm{O}(\mathrm{kg})$ & $\mathrm{CH}_{4}(\mathrm{Kg})$ & $\mathrm{SO}_{2}(\mathrm{~kg})$ \\
\hline Steel* & 2.3065 & 0.0095 & 0.00007 & 0.00004 & 0.0145 \\
Aluminum* & 3.4335 & 0.013 & 0.000105 & 0.000065 & 0.021 \\
Copper & 6.536 & 0.02319 & 0.00019 & 0.00016 & 0.03561 \\
Plastics & 3.113 & 0.01049 & 0.00009 & 0.00008 & 0.01475 \\
Iron* & 3.114 & 0.00889 & 0.00009 & 0.00006 & 0.01458 \\
Concrete /Cement * & 0.835 & 0.0025 & 0 & 0 & 0.00001 \\
\hline
\end{tabular}

*Only mean values are considered.

Table 2. Bath data source giving $\mathrm{CO}_{2}$ emission in $\mathrm{kg} / \mathrm{kg}$ of inventory materials (Hammond and Jones, 2008).

\begin{tabular}{ccccccc}
\hline Inventory materials & Steel & Copper & Iron & Concrete & Plastics & Aluminium \\
\hline${ }^{*} \mathrm{CO}_{2}$ emission in $\mathrm{kg} / \mathrm{kg}$ & 2.83 & 3.0 & 1.91 & 0.95 & 2.53 & 8.26 \\
\hline
\end{tabular}

* Only mean values are considered.

from Bath University data source as well (Hammond and Jones, 2008), for checking up the degree of discrepancy of results (if any), since LCA has been known to be process specific and country specific (Blengini, 2008).

$\mathrm{Ei}$, the embodied energy data of the inventory items were also adopted from both the Danish model ((Schleisner, 2000), and corroborated from Bath University data sources as well (Hammond and Jones, 2008).

Respective Gi values of GHGs of different inventory items, as are commonly used in OE devices, are shown below in table 1, giving the data base from Danish model. The Gi values of respective inventory items as per Bath data source are shown in table 2 , giving the emission characteristics of $\mathrm{CO}_{2}$ only. Likewise in table 3 is shown the data base as regards embodied energy of respective inventory items of OE devices, for both Danish model as well as of Bath University data source. These three tables, giving the respective data base for estimating LCA and EA of OE systems are shown in Tables 1, 2 and 3.

\section{CASE STUDIES OF OE DEVICES}

In order to make LCA and EA studies, both lifetime and annual power generation data of different OE devices are required to be availed, in addition to the mass of all the inventory items of the device concerned. Thus knowing the life of a device, its annual power production and inventory data- both emission characteristics and energy pay back periods can be estimated from computation of Tables 1 and 2, and equation 1; as also of Table 3 and equation 2, respectively.

Four case studies as made from the above premise are appended below in Fig. 1.

\section{LCA AND EA STUDIES OF 750kW PELAMISTYPE WAVE ENERGY CONVERTER}

Pelamis is a cylindrical type wave energy converter consisting of semi-submerged structure with cylindrical sections linked by hinged joints, as shown below in Fig.1. Its life period is reported to be around 20 years (Parker et al., 2007) with annual power generation of $2.5 \mathrm{GWh}$, if placed in Ireland coast (Dalton et al., 2010). Thus its lifetime power production would be $50 \mathrm{GWh}$. The distribution of mass of inventory materials of $750 \mathrm{~kW}$ Pelamis unit was learnt to be broadly constituting of steel: $380,000 \mathrm{~kg}$ and copper: $15000 \mathrm{~kg}$ (Taylor, 2006).

The life time emission characteristics of Pelamis in g/ $\mathrm{kWh}$, could then be estimated employing the equation 1 and making computation of the above data with table 1 , that gives mass of emitted gases in $\mathrm{kg} / \mathrm{kg}$ of the inventory materials, as per the Danish model. The GHG equivalent of respective gases could also be determined multiplying the emission in $\mathrm{g} / \mathrm{kWh}$ with their respective global warming potential (GWP) value; which for $\mathrm{CO}_{2}, \mathrm{~N}_{2} \mathrm{O}$ and $\mathrm{CH}_{4}$ are ' 1 ', ' 310 ' and ' 21 ', respectively. The results thus obtained, are shown below in Table 4 .

It would be evident from the above table that emission of $\mathrm{CO}_{2}$ is only of relevance in assessment of GHG, despite its low GWP of only ' 1 '; mainly because of its much

Table 3. Energy requirement in MJ / kg of the inventory materials of OE devices.

\begin{tabular}{lccccccc}
\hline M aterials & Steel & $\begin{array}{c}\text { Ir on /Cast } \\
\text { ir on }\end{array}$ & Copper & Aluminium & Glass & $\begin{array}{c}\text { Concrete } \\
\text { /Cement }\end{array}$ & Plastics \\
\hline $\begin{array}{l}\text { Embodied } \\
\text { Energy MJ/kg }\end{array}$ & 25.65 & 36.3 & 78.2 & 39.15 & 8.1 & 3.68 & 45.7 \\
$*$ & & & & & & \\
$\begin{array}{l}\text { Embodied } \\
\text { Energy }-\mathrm{MJ} / \mathrm{kg}\end{array}$ & 25.4 & 25 & 70 & 34.1 & 18.50 & 3.01 & 45.7 \\
$* * *$ & & & & & & \\
\hline
\end{tabular}

*Danish model (Schleisner, 2000), ** Bath data (Hammond and Jones, 2008). 
Table 4. Emission of gases in $\mathrm{g} / \mathrm{kWh}$ of $750 \mathrm{~kW}$ Pelamis.

\begin{tabular}{lcccccc}
\hline Gases & $\mathrm{CO}_{2}$ & $\mathrm{NO}_{x}$ & $\mathrm{~N}_{2} \mathrm{O}$ & $\mathrm{CH}_{4}$ & $\mathrm{SO}_{2}$ & $\begin{array}{c}\text { Total GHG equivalent } \\
\text { of gases }\end{array}$ \\
\hline Amount in $\mathrm{g} / \mathrm{kWh}$ & 19.49 & 0.079 & 0.0006 & 0.0003 & 0.12 & 19.68 \\
\hline
\end{tabular}

higher degree of emission compared to other gases. Because of the importance of $\mathrm{CO}_{2}$, its emission was checked up from Bath University data base also as per table 2, which on computation yielded the value of $22.41 \mathrm{~g} /$ $\mathrm{kWh}$. Both these two values fairly tallied with that of Parker et al. (2007) giving $\mathrm{CO}_{2}$ emission to be $22.8 \mathrm{~g} / \mathrm{kWh}$. EPBP values as estimated from computation of Table 3 and Equation 2, based from annual energy production of Pelamis, showed the value of 1.21 year and 1.18 years, for Danish model and Bath data respectively.

\section{CASE STUDY OF 7MW WAVE DRAGON}

Wave Dragon (WD) is an overtopping type of wave energy converter. It focuses the incoming waves towards a huge reservoir (a floating ramp) with two wave reflectors and overtopping the reservoir water to run a number of turbines by converting the pressure head of water to power generation, as shown below in Fig.2.

It has been claimed that its annual power generation when placed in Wales Coast would be $20 \mathrm{GWH}$ (Millar et al., 2007). Also its life is claimed to be 50 years (Tedd, 2007) thereby with life time power production of $1000 \mathrm{GWh}$.

Its inventory data has been shown below in Table 5 (Russell, 2007).

Based from above data and table 1, giving emission characteristics of inventory items as per the Danish model, computation made on life time emission of gases of 7MW Wave Dragon is shown below in Table 6.

Bath University data of $\mathrm{CO}_{2}$ emission estimated from table 2, yielded results as $31.79 \mathrm{~g} / \mathrm{kWh}$, which is a little higher value than that, availed from Danish model.

Computation of EPBP values, on the basis of $20 \mathrm{GWh}$ annual power generation of Wave Dragon, showed values of 1.75 years and 1.57 years, for Danish model and Bath data, respectively.

\section{CASE STUDY OF 100MW CLOSED CYCLE OTEC}

Electricity from OTEC is generated utilising the small temperature difference between warm surface seawater and deep cold seawater, usually following a Rankin cycle heat engine (Green and Guenther, 1990). OTEC however, requires power for its operations to generate the power. Hence, the terms gross energy output and the net energy availability comes up for OTEC schemes; the latter being usually 65 percent from its gross energy output, the value of which increases with larger sized OTEC plants (Vega, 1999).

In case of 100MW OTEC plant, net energy may obviously be presumed to be $75 \%$ of the gross power generated. Presuming the capacity factor to be at least $30 \%$ (as observed for most of $\mathrm{OE}$ schemes), annual power production from $100 \mathrm{MW}$ CC-OTEC would be = $100 * 0.75 * 0.3 * 365 * 24=191.7 \mathrm{GWh}$; with life time power production of $5913 \mathrm{GWh}$, considered for its 30 years life period. The mass of construction materials of the above OTEC plant is shown below in Table 7.

Life time emission of $\mathrm{CO}_{2}$ estimated from the above data with computation as per equation 1 , and table- 1 giving data of Danish model $=27.18 \mathrm{~g} / \mathrm{kWh}$, with GHG equivalent

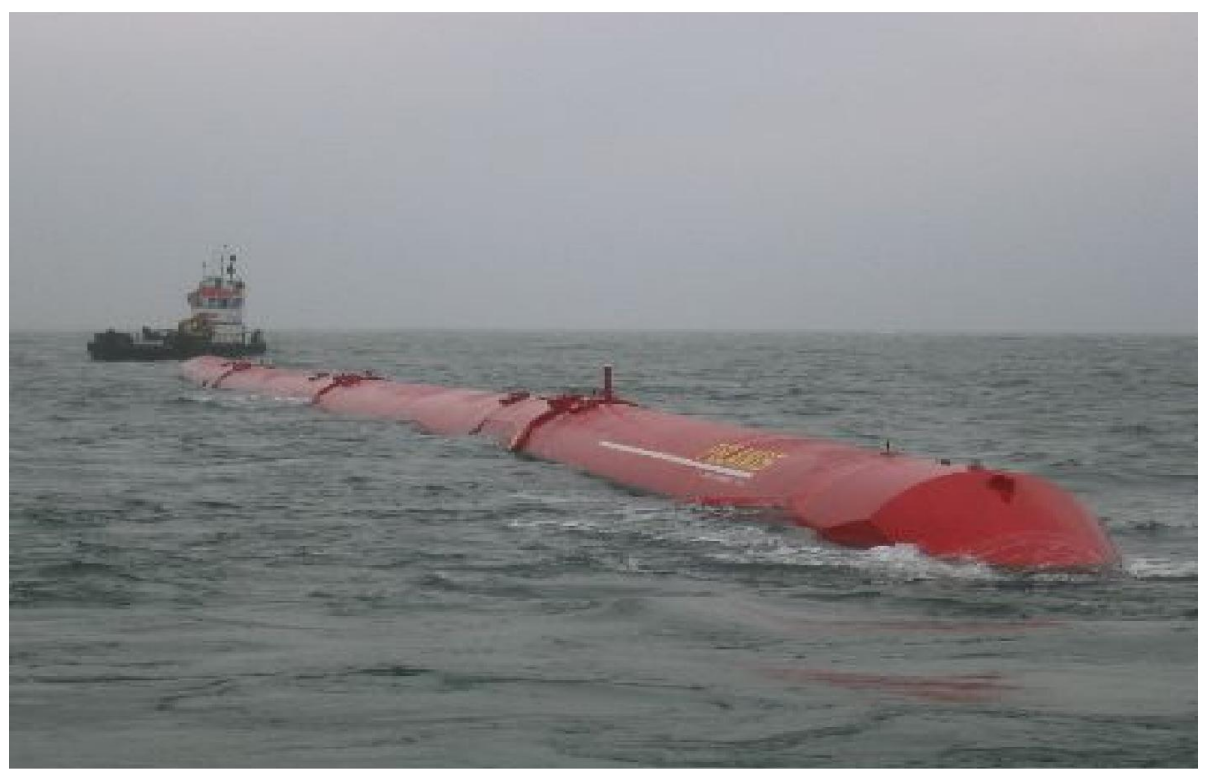

Fig. 1. Diagram of Pelamis at sea. Source: <http://www.pelamiswave.com/media/pelamisbrochure.pdf > [29.7.2009]. 
Table 5. Inventory data of 7MW Wave Dragon (Russell, 2007).

\begin{tabular}{lcccccc}
\hline Inventory materials & Steel & Aluminium & Copper & Plastic & Iron & Concrete \\
\hline Mass(in kg) & 553000 & 24100 & 69300 & 31540 & 120920 & 31068000 \\
\hline
\end{tabular}

Table 6. Emission of gases from 7 MW Wave Dragon.

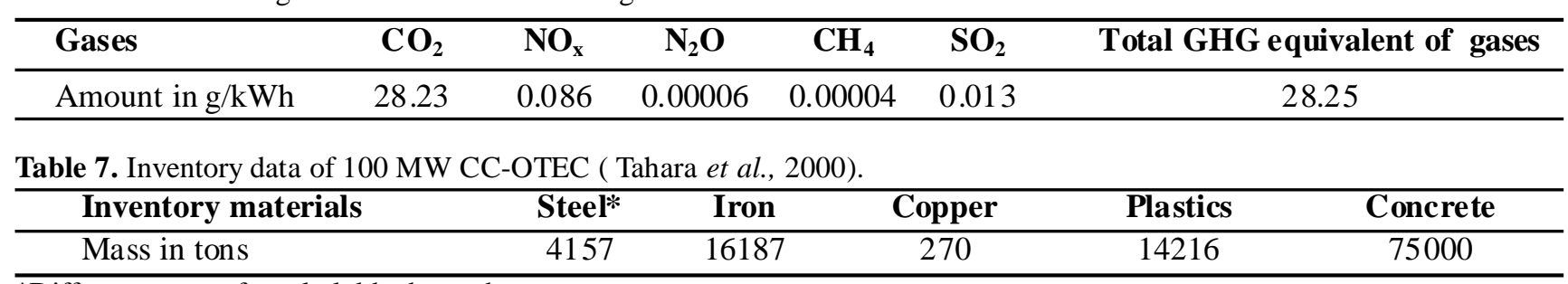

*Different types of steel clubbed together

of gases $=27.37 \mathrm{~g} / \mathrm{kWh}$. Bath data results yields $\mathrm{CO}_{2}$ emission to be $=26.38 \mathrm{~g} / \mathrm{kWh}$.

In addition to the above emission data, in case of OTEC the operational stage emission has also to be taken into account, as per equation 1; unlike the wave schemes. This needs adding up $\mathrm{CO}_{2}$ emission from the working fluid $\mathrm{NH}_{3}$ plus other sources of operational stage emission. The former was estimated to be $0.49 \mathrm{~g} / \mathrm{kWh}$ from the inventory data of Japanese researchers (Tahara et al., 2000); whereas the latter is reported to be a little less than $1 \mathrm{~g} / \mathrm{kWh}$ (Green and Guenther, 1990), presumed as $0.8 \mathrm{~g} / \mathrm{kWh}$ - thus totalling $1.29 \mathrm{~g} / \mathrm{kWh}$.

Adding up the above value during operational stage of CC-OTEC, its life time emission would be $=28.47 \mathrm{~g} / \mathrm{kWh}$, as per Danish model and $27.67 \mathrm{~g} / \mathrm{kWh}$, as per Bath data source. It may be relevant to add that employing data source of NIRE-LCA software, which the Japanese researchers used (Tahara et al., 2000), the value arrived at was only $24.08 \mathrm{~g} / \mathrm{kWh}$ for $100 \mathrm{MW}$ CC-OTEC.

EPBP of $100 \mathrm{MW}$ CC-OTEC, based from its net annual power production of $197.1 \mathrm{GWh}$ and computation with equation 2 and table 3 data, was estimated to be $=2.35$ years from Danish model and 3.07 years from Bath data source.

\section{CASE STUDY OF SEVERN BARRAGE PROPOSAL, UK}

This project proposes to construct a $15-18 \mathrm{~km}$ long barrage from Cardiff to Weston Super-mare, UK, creating a basin area of $480 \mathrm{~km}^{2}$, for holding high tide water of Severn river having mean tidal range $7 \mathrm{~m}$ (Sir Robert Mc Alpine \& sons Ltd 1986). Annual power output from this barrage is expected to be $17 \mathrm{TWh}$, with the life period of

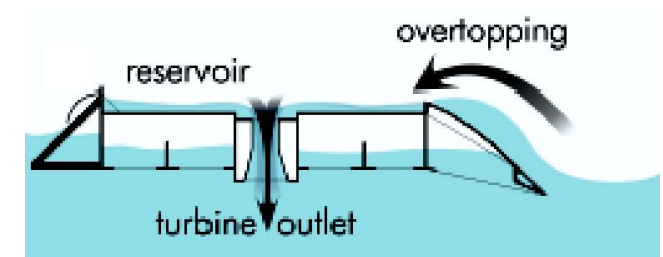

Fig. 2. Mode of operation of power capture in Wave D ragon (Kofoed et al., 2006).
100 years (Woollcombe Adams et al., 2009).

The inventory materials required for constructing the barrage were reported to be mainly consisting of steel, copper and concrete (including cement), with their mass requirement of 588.8 kilo ton $(\mathrm{kt}), 43.2 \mathrm{kt}$ and $3800 \mathrm{kt}$, respectively (Woollcombe Adams et al., 2009).

The emission of $\mathrm{CO}_{2}$ may be determined from the above data base making computation of equation 1 and table 1 . But in order to determine its life time emission, the results are to be added with $2 \%$ extra emission required for transportation as also of emission for operational \& maintenance, which is around 2days/year in its life of 100 years (Elliott, 2004).

Computation of all these emission data divided by its life time power generation extending 100 years, the value of $\mathrm{CO}_{2}$ emission showed $3.01 \mathrm{~g} / \mathrm{kWh}$ for Danish model and $3.26 \mathrm{~g} / \mathrm{kWh}$ from Bath data source.

Computation of EPBP values, on the basis of annual power generation of the Severn barrage showed values of 0.53 years and 0.48 years, for Danish model and Bath data, respectively.

\section{CRITICAL APPRAISAL OF RESULTS}

It could be observed from the above results that Severn barrage project with 100 years life and high power generation capability showed minimum values of both $\mathrm{CO}_{2}$ emission and energy payback period. In fact, these values are mainly influenced from the capability of annual power generation of the device concerned, its life period as well as of the mass and type of inventory materials of the device concerned.

It is to be noted that the above stated $750 \mathrm{~kW}$ Pelamis if placed in Portugal coast would have produced half the power than that availed (2.5 GWh annually) from its placement in Ireland coast (Dalton et al., 2010). Obviously, both $\mathrm{CO}_{2}$ emission and energy payback period would have shown just double the value than that estimated from its application in Ireland coast. Likewise, if the life period of Wave Dragon were considered to be of 30 years duration ( like OTEC), its values on $\mathrm{CO}_{2}$ emission and energy payback period would have shown 
Table 8. Data from LCA studies of OE systems compared with other energy types.

\begin{tabular}{lccccccc}
\hline $\begin{array}{l}\text { Device } \\
\text { concerned }\end{array}$ & Pelami s* & $\begin{array}{l}\text { W ave* } \\
\text { Dragon }\end{array}$ & CC -OTEC* & $\begin{array}{c}\text { Severn* } \\
\text { B arrage }\end{array}$ & $\begin{array}{c}\text { Solar } \\
* *\end{array}$ & $\begin{array}{c}\text { Bio- } \\
\text { fuels } \\
* *\end{array}$ & $\begin{array}{c}\text { Wind } \\
\text { energy } \\
* *\end{array}$ \\
\hline $\begin{array}{l}\mathrm{CO}_{2} \mathrm{~g} / \mathrm{kWh} \\
\% \mathrm{CO}_{2} \text { saved }\end{array}$ & 19.49 & 28.23 & 28.47 & 3.01 & 35 & 25 & 6 \\
\begin{tabular}{l} 
EPBP in years \\
\hline
\end{tabular} & 1.21 & 1.75 & 2.35 & 0.53 & - & - & - \\
\hline
\end{tabular}

*Only danish model considered; **Minimum values are considered

\section{LCA studies of OE systems compared with other Renewable energy types}

- \% CO2 in $\mathrm{g} / \mathrm{kWh} \quad \% \mathrm{CO} 2$ saved EPBP in years

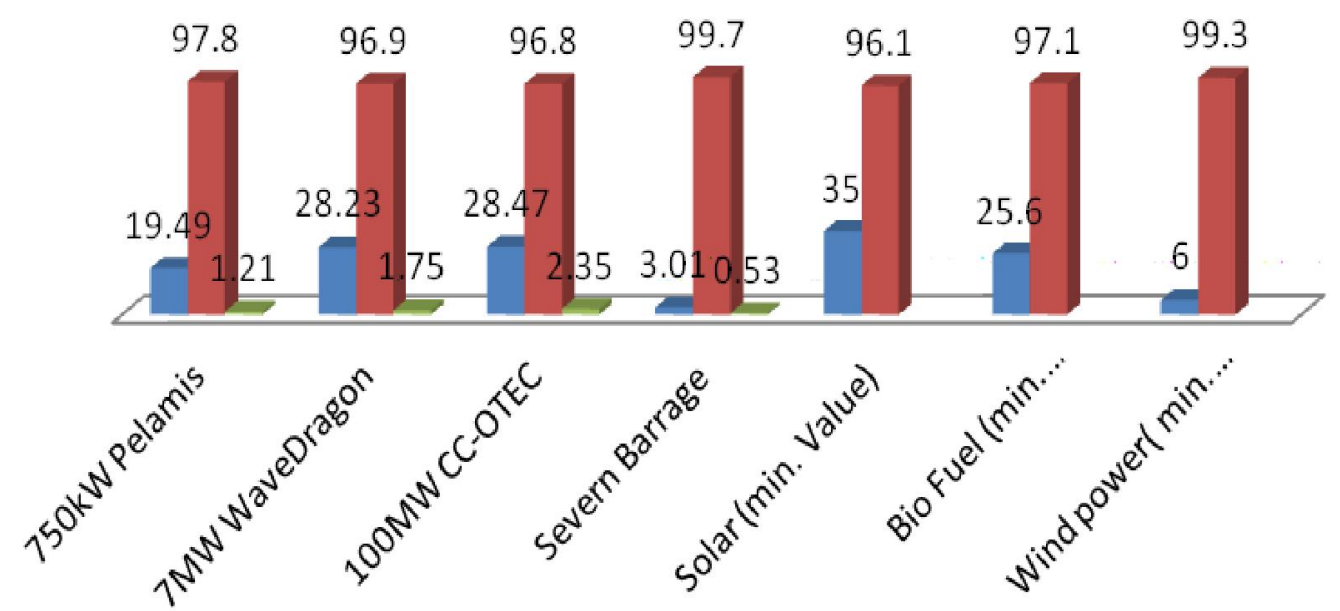

Fig.3. $\mathrm{CO}_{2}$ emission of $\mathrm{OE}$ systems compared with other renewable energy types.

$40 \%$ higher values than that estimated in the present study considered for 50 years life.

Also, the discrepancy (though minor) of the results between Danish model and Bath data source, for the same device, are caused because of the varied data base of respective inventory items concerned.

It may be relevant to add that the values obtained from LCA and EA studies pertained only for the respective OE device concerned, without considering the input as would accrue for power transmission from cable lines etc. However, the results prove to be important as one of the assessment tools, making comparative study of the competing OE devices for their acceptability.

It has hence been considered important to compare the above results of OE systems with other renewable energy types, like solar, bio-Fuels and wind energy, as well as determining the GHG saving compared to coal fired generator. These studies have been made in the subsequent section.

\section{COMPARATIVE STUDY ON CO SAVING PERCENTAGE}

$\mathrm{CO}_{2}$ emission from coal fired generator, as obtained from LCA studies was found to be $900 \mathrm{~g} / \mathrm{kWh}$ (Odeh and
Cockerill, 2008). Considering this to be the $100 \%$ emission, the percentage of $\mathrm{CO}_{2}$ saved from the application of an energy device would be

$=100$ - Emission of device concerned in $\mathrm{g} / \mathrm{kWh} * 100 / 900$ (3) It has also been noted that emission of $\mathrm{CO}_{2}$ from solar power may vary between $58 \mathrm{~g} / \mathrm{kWh}$ and $35 \mathrm{~g} / \mathrm{kWh}$, depending on the technology adopted (Parliamentary office post note, 2006). In case of bio-fuels it varies between $25 \mathrm{~g} / \mathrm{kWh}$ and $93 \mathrm{~g} / \mathrm{kWh}$, depending on the type of bio-mass used (Parliamentary office post note, 2006). Wind energy shows the least value of $6 \mathrm{~g} / \mathrm{kWh}$ (Crawford, 2009).

Based from the above data, GHG saving percent of different types of $\mathrm{OE}$ device, as determined from equation 3 are shown in Table 8 and Fig. 3, given below.

\section{Conclusion}

It could be inferred that $\mathrm{CO}_{2}$ is the main contributor in GHG emission. Emission of $\mathrm{CO}_{2}$ as determined from LCA studies and EPBP values estimated from EA studies, depend on annual energy production, device life, as also of mass and type of the inventory materials required. Amongst the OE systems, it is the barrage that showed maximum efficiency as regards $\mathrm{CO}_{2}$ saving as also of 
achieving minimum energy pay back period. All the $\mathrm{OE}$ devices showed more than $95 \% \mathrm{CO}_{2}$ saving than the coal power plant. Amongst the other renewablle energy types, it is only the wind energy that showed minimum emission, whence solar power showed maximum values, with bio-fuels comparable to the OE systems. Values of EPBP varied between less than one year to two years, with only OTEC showing a little higher than two years. Though LCA studies are known to be counry specific and process specific, but results obtained from the present study, carried out using both Danish model and Bath data source, broadly conformed with each other.

\section{ACKNOW LEDGMENTS}

The authors acknowledge their thanks to Dr. H.C. Sorensen and Dr. Ian Russel of Wave Dragon, for providing data as regards inventory matrertials and other relevant details on Wave Dragon. Thanks are also due to Dr C. Taylor of Pelamis farm, OPD, as regards inventory data on Pelamis.

\section{REFERENCES}

Blengini, G.A. (2008).Using LCA to evaluate impacts and resources conservation potential of composting: A case study of the Asti District in Italy. Resources, Conservation and Recycling, 52(12):1373-1381

Crawford, R.H. (2009).Life cycle analysis and greenhouse emissions of wind turbines and the effect of size on energy yield. Renewable and Sustainable E nergy Reviews, 13(9): 2653-2660.

Dalton, G. J., Alcorn, R. and Lewis, T.(2010).Case study feasibility analysis of the Pelamis wave energy converter of Ireland, Portugal and North America. Renewable Energy, 35:443-445.

Elliott, E. (2004).Chapter-6 Tidal Power.' in Renewable energy. ed. by Boyle, G., Oxford University Press, 196-242

Green, H.J. and Guenther, P.R., (1990) .Carbon Di-oxide release from OTEC cycles. International conference on ocean energy recovery. Report -SERI/TP-253-3594; UC category: 262 DE 89009504, held 28-30 $0^{\text {th }}$ November 1989 at Hawaii.

Hammond, G and Jones, C., (2008) Data on LCA \& EA [Communication from Dept of Mechanical Engineering, University of Bath, UK] available from <www.bath.ac.uk/ mech-eng/sert/embodied $>$ [1st August 2009]

Helias, A. Udo de, H. and Reinout, H. (2007). Life cycle assessment for energy analysis and management, Applied Energy, 84: 817-827.

ISO 14040 (2006). Environmental management. Life cycle assessment. Principles and framework. British Standards Institute, London

Kofoed J. P., Friggard P., Friis-Madsen E. and Sorensen H. C.(2006). Prototype testing of the wave energy converter wave dragon. Renewable Energy, 31(2): 181-189.

Millar, D.L., Smith, H.C. M. and Reeve, D.E. (2007). Modelling analysis of the sensitivity of shore line change to a wave farm'. 0 cean Engineering, 34(5-6): 884-901

Odeh, N. A., Cockerill, T.T.(2008). Life Cycle analysis of UK coal fired power plants. Energy Conversion and $M$ anagement, 49: 212-220

Parker, R. P. M., Harrison, G. P. and Chick J. P.(2007). Energy and carbon audit of an off-shore wave energy converter. J . Power and Energy, 221(8): 1119-1131

Parliamentary office of science \& Technology, post note; Oct.2006, no-268[availed from] <http://www.parliament.uk/ documents/post/postpn268.pdf $>$ [5.7.10]

Russel, I. (2007). Inventory materials of 7M W Wave D ragon [Personal communication from Business development manager of Wave Dragon firm]

Schleisner, L. (2000).Life cycle analysis of a wind farm and related externalities. Renewable E nergy, 20: 279-288

Sir Robert Mc Alpine and Sons Ltd (1986). Tidal Power from the Severn, Engineering and Economic Studies: Cardiff Weston Scheme, Severn Tidal Power Group, Chapter 8, 116

Tahara, K., Kojima,T. and Inaba, A. (2000). Estimation of ocean thermal energy conversion system by using LCA methodology. OTE C .8:31-41 [In Japanese]

Taylor, C. (2006) Inventory Materials of $750 \mathrm{~kW}$ Pelamis [Personal communication from Chief Engineer of Pelamis farm, OPD]

Tedd, J. (2007). Testing, analysis, and control of wave dragon wave energy converter. "P hD Thesis (101207)", D enmark; Alborg U niversity.

Thresher, R. and Musial, W. (2010). Ocean renewable energy's potential role in supplying future electrical need. Special issue on Marine Renewable Energy, Oceanography, 23 (2):16-21.

Vega, L.A., (1999) ‘Ocean Thermal Energy Conversion’, OTEC, $1-22$

Woollcombe-Adams C., Watson M.., and Tom S., (2009). Severn Barrage tidal project: Implication for carbon emissions. Water \& Environment J ournal, 23(1): 63-68. 